\title{
MAS̆LAHAH DALAM VAKSINASI: ANALISIS FATWA MALAYSIA DAN INDONESIA
}

\section{Mașlahah in Vaccination: An Analysis of the Fatwa of Malaysia and Indonesia}

\author{
Norhidayah Pauzi * \\ Saadan Man **
}

\begin{abstract}
Vaccination is one of the preventative measures taken to prevent harmful life-threatening illnesses. However, today, more people are rejecting the vaccine based on mistaken information and wrong claims about the vaccine. Furthermore, different in status fatwas on the use of vaccines between Malaysia and Indonesia has added more concern for them on vaccination. This article analyzes by comparison the medical fatwa issued by the Malaysian Fatwa Committee and the Indonesian Ulama Council. Library and interview methods are used together to complement the study. The findings show that Malaysia permit the use of Meningitis vaccine based on the approach of akhaf al-darārayn and mașlahah darūriyyah for the purpose of saving lives, in contrast to Indonesia that bans the use of Meningitis vaccine as it was found
\end{abstract}

* Senior Lecturer, Department of Fiqh and Usul, Academy of Islamic Studies, University of Malaya, da_my85@um.edu.my

** Senior Lecturer, Department of Fiqh and Usul, Academy of Islamic Studies, University of Malaya, saadan@um.edu.my 
to have contact with impurified sources of pigs and there are other alternatives for halal vaccine.

Keywords: Halal, Fatwa, Vaksin, Mașlaḥah

\section{PENGENALAN}

Kaedah rawatan pada masa kini semakin berkembang seiring dengan berlakunya penularan penyakit berjangkit yang membimbangkan. Dalam bidang farmaseutikal, bioteknologi banyak digunakan untuk menghasilkan pelbagai jenis vaksin sebagai langkah pencegahan kepada wabak penyakit berjangkit tersebut. Namun, timbul keraguan dalam kalangan masyarakat Muslim tentang kewajaran menggunakannya terutama vaksin yang bersumberkan daripada bahan haram atau bahan najis. Masyarakat Muslim turut mempersoalkan penggunaan beberapa vaksin yang dilaksanakan oleh kerajaan ekoran kebimbangan terhadap status halal vaksin terbabit. Apatah lagi apabila terdapat perbezaan status hukum terhadap penggunaan vaksin Meningococcal Meningitis di antara Malaysia dan Indonesia. Hal ini mendedahkan kepada kelemahan dalam penyelarasan fatwa yang dikeluarkan oleh institusi fatwa kerana melibatkan isu dan permasalahan yang sama malah menyentuh kepentingan nasional. Justeru, artikel ini memfokuskan perbincangan kepada analisis perbandingan fatwa perubatan khasnya penggunaan vaksin Meningococcal Meningitis di antara Malaysia dan Indonesia.

\section{MAȘLAHAH DARI PERSPEKTIF MAQĀṢID AL-SYARI'AH}

Mașlahah adalah perkataan bahasa Arab yang berasal daripada perkataan șalaha, yașluhu, șulüḥan yang bererti baik atau elok. Maṣlahah adalah setiap perkara yang mengandungi kebaikan dan kemanfaatan kepada manusia serta menolak kepada kerosakan (mafsadah). ${ }^{1}$ Manakala dari segi istilah pula, mașlahah adalah manfaat yang ditujukan Allah SWT kepada manusia demi

Ibn Manẓūr al-Afrīqī al-Mișri, Lisān al- 'Arab (Bayrūt: Dār Șādir, 1990), 2: 516. Lihat juga, Ḥusayn Ḥāmid Ḥasān, Nazariyyah alMașlahah fì al-Fiqh al-Islāmī (al-Qāhirah: Maktabah al-Mutanabbi, 1981), 3-4. 
memelihara lima perkara yang utama iaitu agama, nyawa, akal, keturunan dan harta benda. ${ }^{2}$

Menurut Imam al-Ghazālī, mașlahah adalah memelihara tujuan dan matlamat syarak manakala tujuan memelihara matlamat syarak kepada manusia ada lima iaitu memelihara kesucian dan ketinggian agama; memelihara keselamatan diri; memelihara kebaikan dan kecerdasan akal fikiran; memelihara kebaikan keturunan; dan memelihara kesucian dan keselamatan harta benda. Justeru, setiap perkara dan tindakan yang mengandungi pemeliharaan dan kawalan terhadap lima perkara penting ini dinamakan mașlahah sementara setiap perkara dan tindakan yang boleh mencabuli lima perkara ini dinamakan mafsadah (kerosakan) dan penolakan atau pencegahannya pula dinamakan mașlahah. ${ }^{3}$

Berdasarkan pentakrifan di atas, dapat difahami bahawa mașlaḥah adalah setiap perkara yang membawa kebaikan dan menolak keburukan kepada manusia untuk memelihara lima perkara yang utama iaitu agama, nyawa, akal, keturunan dan harta benda walaupun kadangkala ia bertentangan dengan kehendak individu dan masyarakat awam. Ini kerana ada kalanya individu dan masyarakat awam menganggap sesuatu perkara tersebut membawa kebaikan kepada mereka namun pada pandangan

2 Abū Ishạāq al-Syātịīi Ibrāhīm bin Mūsā, al-Muwāfaqāt fì 'Ilm Uṣūl al-Syarī'ah (Bayrūt: Dār al-Kutub al-'Ilmiyyah, 1991), 3. Lihat juga, Fakhr al-Dīn Muhammad bin 'Umar bin Husayn al-Rāzī, al-Mahșūl fì 'Ilm Ușūl al-Fiqh (Bayrūt: Mu’assasah al-Risālah, 1992), 6: 162. Lihat juga, Quṭb Mușțafā Sānū, Mu’jam Muștalahật Uṣūl al-Fiqh (Bayrūt: Dār al-Fikr, 2000), 431. Lihat juga, Kotb Rissouni dan Najmaldeen K. Kareem al-Zanki, "Application of Maqasid in the Jurisprudence of Minorities: The Case of "Zawaj al-Maslahah" in the West", Jurnal Fiqh 12 (2015), 141.

Abū Hāmid Muḥammad bin Muḥammad al-Ghazālī, al-Mustaşāa min 'Ilm al-Ușūl (al-Madīnah: Syirkah al-Madīnah al-Munawwarah li al-Ṭibā'ah wa al-Nasyr, 1992), 2: 482. Lihat juga, Mohd. Nor Deris, "Keterikatan Mașlahah sebagai Sumber Hukum dengan Kepentingan Semasa dan Setempat di Malaysia," dalam Fiqh Malaysia, ed. Paizah Ismail dan Ridzwan Ahmad (Universiti Malaya: Akademi Pengajian Islam, 2000), 128. Lihat juga, Mohamad Zaidi Abdul Rahman, "Aplikasi Maqasid al-Shari'ah dalam Pentadbiran Negara: Satu Tinjauan Sejarah Islam,” Jurnal Fiqh 12 (2015), 30. 
syarak perkara tersebut membawa keburukan kepada mereka dan demikian juga sebaliknya.

Mașlaḥah terbahagi kepada tiga peringkat iaitu memelihara keperluan asasi (maṣlahah darūriyyah), memelihara kepentingan manusia dalam keperluan sampingan (mașlahah häjiyyah) dan memelihara keselesaan dan keharmonian hidup (mașlahah tahsiniyyah). Maṣlaḥah darūriyyah merujuk kepada pemeliharaan dalam aspek utama kehidupan manusia khususnya pemeliharaan terhadap agama, diri, harta, akal dan keturunan. Mașlahah darūriyyah dalam aspek ușūl ibadat adalah beriman kepada Allah SWT, mengucap dua kalimah syahadah, melaksanakan sembahyang, berpuasa di bulan Ramadan dan melaksanakan ibadah haji ke Baitullah bagi orang yang berkemampuan termasuk dalam pemeliharaan terhadap agama. Dalam aspek ușūl adat pula, makanan, pakaian dan tempat tinggal termasuk dalam pemeliharaan terhadap nyawa dan akal. Manakala dalam aspek $u s \underline{u} l$ muamalat, majlis perkahwinan dan akad jual beli termasuk dalam pemeliharaan terhadap keturunan dan harta. ${ }^{4}$

Maṣlaḥah hajjiyyah merupakan sesuatu yang berkaitan dengan keperluan umum manusia namun ia tidak menyamai dengan maṣlaḥah darūriyyah. Maṣlaḥah haajjiyyah sering kali berlaku dalam perkara yang berkaitan dengan ibadat, adat, muamalat dan jenayah. Dalam aspek ibadat, Islam memberikan keringanan (rukhșah) kepada pesakit dan orang yang bermusafir. Dalam aspek adat, Islam mengharuskan pemburuan ke atas haiwan serta mencari makanan yang halal lagi baik. Dalam aspek muamalat pula, Islam mengharuskan jual beli secara hutang seperti $b a y^{6}$ salam dan seumpama dengannya. Manakala dalam aspek jenayah, pihak yang berautoriti seharusnya melaksanakan hukuman liwat, diat dan seumpamanya ke atas pelaku jenayah yang terlibat. ${ }^{5}$

Maṣlahahtahsiniyyah merupakan perkara yang memperelokkan keadaan serta memberikan kebaikan kepada manusia seperti

4 Adnān Muhammad Jum'at, Raf' al-Haraj fì Syarī'ah al-Islāmiyyah, ed. ke-3 (Dimasyq: Dār al-'Ulūm Insāniyyah, 1993), 14. Lihat juga, 'Umar Sulaymān 'Abd Allāh al-Asyqār, Nazariyyat fì Ușūl al-Fiqh (Jordān: Dār al-Nafă'is, 1999), 225.

5 Al-Asyqā̄, Nazariyyat fì Ușūl al-Fiqh, 225; Muhammad Jum'at, Raf"al-Haraj, 15. 
mengamalkan budaya kebersihan, menutup aurat, menjaga adab ketika makan dan minum, bersedekah dan sebagainya. Ini menunjukkan bahawa akhlak mulia adalah sebahagian daripada penjagaan budi pekerti yang menghasilkan keindahan kepada tingkah laku terhadap sesebuah masyarakat. Mașlahah tahsiniyyah sering kali berlaku dalam perkara yang berkaitan dengan ibadat, adat, muamalat dan jenayah. Dalam aspek ibadat, Islam mengharuskan perhiasan dan memperbanyakkan melakukan perkara sunnah dalam beribadat kepada Allah SWT. Dalam aspek adat, ia merangkumi adab dalam makanan dan minuman, menjauhi makanan yang bernajis dan minuman yang keji seperti arak dan seumpamanya. Seterusnya dalam aspek muamalat pula, diharuskan perlantikan saksi serta melantik wanita menjadi imam. Dalam aspek jenayah, Islam menghalang pembunuhan ke atas hamba yang merdeka, wanita, kanak-kanak semasa berjihad di jalan Allah SWT. ${ }^{6}$

Para ulama menetapkan bahawa mașlahah darūriyyah mesti diutamakan daripada mașlahah hājiyyah dengan alasan jika mașlahah darūriyyah tidak dilakukan nescaya hidup manusia tidak sempurna di dunia dan akhirat sedangkan membelakangi mașlahah hājiyyah tidak menyebabkan kecacatan sistem hidup manusia. Ia cuma mengakibatkan kesusahan dan kesukaran sahaja. Lantaran itu, mașlahah darūriyyah diutamakan. Kemudian, mașlahah hajjiyyah mestilah diutamakan daripada maṣlahah tahsiniyyah kerana ketiadaan mașlahah häjiyyah akan membawa kesulitan hidup berlainan dengan ketiadaan mașlahah tahsiniyyah yang hanya tidak memberikan kesempurnaan dan keselesaan hidup sahaja. $^{7}$

Justeru, mașlahah ḍarüriyyah adalah peringkat paling utama dalam kedudukan maslahah diikuti dengan mașlahah hājiyyah dan kemudian diikuti dengan mașlahah tahsiniyyah. Ulama juga telah menetapkan wujudnya turutan bagi lima perkara yang diutamakan dalam mașlaḥah darūriyyah iaitu kepentingan agama diletakkan pada kelas yang pertama daripada kepentingan nyawa, sementara kepentingan nyawa mestilah diutamakan daripada

Al-Asyqār, Naẓariyyat fì Ușūl al-Fiqh, 225; Muhammad Jum'at, Raf' al-Haraj, 15.

7 Mohd. Nor Deris, "Keterikatan Maslahah,”, 133. 
kepentingan akal, kepentingan akal mestilah diutamakan daripada kepentingan keturunan, kepentingan keturunan pula diutamakan daripada kepentingan harta. ${ }^{8}$

\section{KEPUTUSAN FATWA MUZAKARAH JAWATANKUASA FATWA KEBANGSAAN MALAYSIA DAN MAJELIS ULAMA INDONESIA}

Vaksin adalah bahan yang merangsang penghasilan antibodi dalam tubuh seseorang terhadap penyakit tertentu. Ia mengandungi komposit bahan yang dinyahaktifkan kandungan toksiknya, yang mana kandungan biologi itu diperlukan untuk mengarahkan antibodi terhadap sesuatu penyakit secara semula jadi. Penghasilan vaksin sama seperti penghasilan ubat yang digunakan dalam rawatan perubatan iaitu melalui ujian rawak klinikal yang sangat ketat serta didokumentasikan kesemua kesan sampingan yang berpotensi berlaku. ${ }^{9}$

Dalam pemberian vaksin Meningitis yang wajib diberikan kepada bakal haji dan umrah, timbul keraguan dalam kalangan masyarakat Muslim apabila dimaklumkan vaksin ini mengandungi bahan terlarang. Dalam pada masa yang sama, Majelis Ugama Indonesia telah mengeluarkan fatwa yang mengesahkan lagi bahawa vaksin Mencevax ACW135Y yang dikeluarkan oleh GlaxoSmithKline haram digunakan kerana mengandungi unsur babi. ${ }^{10}$

Walau bagaimanapun, Malaysia mempunyai pandangan yang berbeza dalam isu ini. Malaysia memutuskan bahawa harus mengambil vaksin jenama Mencevax Injection daripada pengeluar

$8 \quad$ Mohd. Nor Deris, "Keterikatan Maslahah,", 133.

9 Malina Osman, "Vaksin: Menerima Pendapat Pakar," laman sesawang Utusan Online, dicapai 22 Disember 2016, http://www.utusan.com. my/rencana/vaksin-menerima-pendapat-pakar-1.364684.

10 Fatwa Majelis Ulama Indonesia telah menetapkan status kehalalan vaksin Meningococcal Meningitis Mencevec adalah haram. Sumber rujukan: "Vaksin Meningitis Italia \& China Halal (Untuk Calon Jemaah Haji dan Umrah)", laman sesawang Majelis Ulama Indonesia, dicapai pada 15 November 2013, https://www.facebook.com/notes/ majelis-ulama-indonesia-mui/vaksin-meningitis-italia-china-halaluntuk-calon-jemaah-haji-dan-umrah/225948397468893. 
Syarikat GlaxoSmithKline kerana produk ini tidak mengandungi bahan daripada sumber haiwan kecuali laktosa daripada susu lembu. ${ }^{11}$ Oleh kerana terdapat perbezaan terhadap status mengenai vaksin Meningococcal Meningitis antara Indonesia dan Malaysia telah menimbulkan kebimbangan dalam kalangan jemaah haji dan umrah sedangkan pengambilan vaksin berkenaan adalah diwajibkan untuk mengelakkan sebarang masalah kesihatan yang serius kepada mereka.

\section{ANALISIS PERBANDINGAN FATWA FARMASEUTIKAL ANTARA MALAYSIA, INDONESIA DAN BRUNEI}

Mașlahah merupakan neraca dalam menentukan hukum yang tidak dinaskan oleh syarak dan mașlahah sentiasa berlaku perubahan mengikut keperluan semasa dan setempat. Islam sebagai sebuah agama yang universal berupaya mengadaptasikan realiti masyarakat setempat dengan perubahan yang berlaku bagi menyelesaikan permasalahan semasa dalam kehidupan masyarakat.

Penyakit Meningococcal Meningitis adalah sejenis penyakit berjangkit yang disebabkan oleh virus dan bakteria Neiserria Meningitis. Jangkitan penyakit ini boleh menyebabkan berlakunya keradangan pada bahagian selaput otak dan saraf tunjang. Semasa musim haji, kadar pembawa penyakit Meningococcal Meningitis meningkat sehingga ke paras setinggi 80 peratus berikutan daripada beberapa faktor antaranya kehadiran jemaah haji daripada pelbagai negara, keletihan fizikal semasa menunaikan

11 Muzakarah Jawatankuasa Fatwa Majlis Kebangsaan Bagi Hal Ehwal Ugama Islam Malaysia Kali Ke-53 yang bersidang pada 27 Nov 2002 telah membincangkan Suntikan Pelalian Vaksin Meningococcal Meningitis oleh Orang Islam. Muzakarah telah memutuskan pelalian meningococcal meningitis Mencevec yang diambil daripada sumber lembu adalah harus. Muzakarah Jawatankuasa Fatwa Majlis Kebangsaan, "Suntikan Pelalian Vaksin Meningococcal Meningitis oleh Orang Islam", laman sesawang Portal Rasmi Fatwa Malaysia, dicapai 9 November 2013, http://www.e-fatwa.gov.my/fatwakebangsaan/suntikan-pelalian-vaksin-meningococcal-meningitisoleh-orang-islam. 
ibadah, suhu persekitaran yang tinggi, kesesakan manusia dan tahap pencemaran udara yang teruk. ${ }^{12}$

Setelah penularan wabak ini semakin meningkat, pada tahun 2001, kerajaan Arab Saudi telah mewajibkan pemberian pelalian vaksin Meningitis jenis Quadrivalent A/C/Y/W135 sebagai syarat pengeluaran visa haji kepada semua negara. Suntikan vaksin berkenaan hendaklah diperakukan oleh pegawai perubatan pada Buku Rekod Rawatan Kesihatan Jemaah Haji dengan menyatakan kuantiti, tarikh suntikan, jumlah dos yang diberikan, cara pemberian, jenis dan nombor kelompok vaksin, tarikh luput dan cop rasmi pengamal perubatan yang bertanggungjawab. ${ }^{13}$

Pada tahun yang sama (2001), Muzakarah Jawatankuasa Fatwa Kebangsaan Malaysia dan Majelis Ulama Indonesia telah mengharuskan penggunaan vaksin Meningitis jenis Quadrivalent A/C/Y/W135 kerana adanya mașlahah awam bagi tujuan menyelamatkan nyawa. Walau bagaimanapun, timbul keraguan berkenaan status halal haram vaksin Meningitis jenis Quadrivalent A/C/Y/W135 apabila Majelis Ulama Indonesia mengeluarkan fatwa dengan mengharamkan penggunaannya kerana mengandungi enzim (medium agar Mueller Hinton Media) daripada babi dalam proses penghasilannya. ${ }^{14}$

Seterusnya, pada tahun 2002, Muzakarah Jawatankuasa Fatwa Kebangsaan Malaysia memutuskan bahawa penggunaan vaksin jenama Monumen yang mengandungi unsur daripada babi adalah

12 Portal Rasmi Fatwa Malaysia, "Suntikan Pelalian Vaksin Meningococcal Meningitis oleh Orang Islam," laman sesawang Portal Rasmi Fatwa Malaysia, dicapai pada 24 Jun 2015, http:// www.e-fatwa.gov.my/fatwa-kebangsaan/suntikan-pelalian-vaksinmeningococcal-meningitis-oleh-orang-islam. Lihat juga, Abd. Rahman, B. Pharm, Vaksin Haji Haram (H. Science Solution: RBC Publishing \& Marketing, 2013), 9-10.

13 Abd. Rahman, B. Pharm, Vaksin Haji Haram, 9-10. Lihat juga, Tabung Haji, "Maklumat Imunisasi," laman sesawang Tabung Haji, dicapai pada 24 Jun 2015, http://www.tabunghaji.gov.my/maklumatimunisasi.

14 Mustafa Abdul Rahman, Kertas Kerja Muzakarah Jawatankuasa Fatwa Majlis Kebangsaan Hal Ehwal Ugama Islam Malaysia, Hukum Suntikan Pelalian Vaksin 'Meningococcal Quadrivalent' oleh Orang Islam, Kertas JKF Bil. 1/53/2002, 2. 
haram digunakan manakala penggunaan vaksin jenama Mencevax yang diambil daripada sumber lembu adalah harus. Fatwa ini dikeluarkan berdasarkan beberapa hujah yang utama iaitu pada tahun 2002, hanya terdapat dua jenis vaksin sahaja di pasaran iaitu vaksin jenama Menomune dan vaksin jenama Mencevax. Vaksin jenama Mencevax keluaran GlaxoSmithKline yang dihasilkan di Belgium dipercayai tidak mengandungi bahan daripada sumber haiwan kecuali laktosa daripada susu lembu dan telah pun mendapat perakuan kelulusan daripada Biro Farmasi, Kementerian Kesihatan Malaysia. Keharusan menggunakan vaksin jenama Mencevax adalah berlandaskan kepada kaedah fiqh الضرورين أخف (mengambil yang lebih ringan antara dua keburukan), meskipun sumber daripada lembu masih belum dapat dipastikan sama ada ia disembelih atau tidak. Ini menjelaskan bahawa penggunaan suntikan vaksin jenama Menomune yang mengandungi unsur babi tidak boleh digunakan sama sekali. ${ }^{15}$

Pada tahun 2010, Indonesia sekali lagi mendedahkan bahawa haram menggunakan vaksin jenama Mencevax kerana mengandungi sumber daripada babi dalam proses penghasilannya. ${ }^{16}$ Fatwa pengharaman vaksin jenama Mencevax oleh Majelis Ulama Indonesia dikeluarkan selepas kajian dan audit yang telah dijalankan terhadap tiga syarikat farmaseutikal yang menghasilkan vaksin Meningitis iaitu GlaxoSmithKline Beecham Pharmaceutical-Belgium, Novartis Vaccine and Diognostics S.r.i. dan Zheijiang Tianyuan Bio Pharmaceutical Co. Ltd.. Kajian yang dijalankan Majelis Ulama Indonesia mendapati bahawa: ${ }^{17}$

i. Vaksin Mencevax ACW135Y yang dihasilkan oleh GlaxoSmithKline \& Beecham Pharmaceutical, Belgium

15 Mustafa Abdul Rahman, Kertas Kerja Muzakarah Jawatankuasa Fatwa Majlis Kebangsaan Hal Ehwal Ugama Islam Malaysia, Hukum Suntikan Pelalian Vaksin.

16 Hendra Utama (Kepala Bidang Standar, Lembaga Pengkajian Pangan, Obat-obatan dan Kosmetika Majelis Ulama Indonesia (LPPOM MUI), Kota Bogor, Indonesia), dalam temu bual dengan penulis, 11 Mei 2015. Lihat juga, Fatwa Majelis Ulama Indonesia, Penggunaan Vaksin Meningitis bagi Jemaah Haji dan Umrah, Nomor: 06 Tahun 2010, Majelis Ulama Indonesia.

17 Fatwa Majelis Ulama Indonesia, Penggunaan Vaksin Meningitis bagi Jemaah Haji dan Umrah. 
pernah bersentuhan dengan bahan yang tercemar dengan babi.

ii. Vaksin Menveo Meningococcal yang dinamakan Menveo Meningococcal Group A, C, W135 and Y Conyugate Vaccine dihasilkan oleh Novartis Vaccine and Diognostics S.r.i. tidak bersentuhan dengan babi atau bahan yang tercemar babi dan telah melalui proses penyucian.

iii. Vaksin Meningococcal yang dinamakan sebagai Menveo Meningococcal Vaccine yang dihasilkan oleh Zheijiang Tianyuan Bio Pharmaceutical Co. Ltd. tidak bersentuhan dengan babi atau bahan yang tercemar babi dan telah melalui proses pencucian.

Pada 16 Julai 2010, Rapat Komisi Fatwa memutuskan hasil perbincangan bahawa: ${ }^{18}$

i. Penghasilan vaksin yang menggunakan babi dalam proses pembuatannya dianggap telah mengambil manfaat daripada babi.

ii. Penghasilan vaksin yang tidak menggunakan babi dalam proses pembuatannya tetapi bersentuhan dengan bahan najis selain babi dapat disucikan kembali.

iii. Penyucian dalam proses pembuatan vaksin di perusahaan Novartis Vaccine and Diognostics S.r.i dan Zheijiang Tianyuan Bio Pharmaceutical Co. Ltd. telah memenuhi syarat-syarat penyucian secara syarak (tathir syar'an).

Majelis Ulama Indonesia menegaskan bahawa walaupun tidak terdapat kesan atau unsur babi tidak dapat dikesan di akhir proses pembuatan vaksin jenama Mencevax keluaran GlaxoSmithKline tetapi Majelis Ulama Indonesia mendapati unsur babi digunakan di peringkat pembenihan di awal proses pembuatan vaksin tersebut. Oleh itu, vaksin jenama Mencevax dikatakan telah tercemar kerana menggunakan bahan daripada babi. Manakala, vaksin jenama 'Menveo Meningococcal Group A, C, W135 and Y Conyugate Vaccine' keluaran Novartis Vaccine and Diognostics S.r.i. dan vaksin jenama 'Menveo Meningococcal Vaccine'

18 Fatwa Majelis Ulama Indonesia, Penggunaan Vaksin Meningitis bagi Jemaah Haji dan Umrah. 
keluaran Zheijiang Tianyuan Bio Pharmaceutical Co. Ltd. adalah vaksin halal. Ini kerana kedua-dua vaksin ini tidak mengandungi sumber daripada babi dan telah pun melalui proses penyucian berulang kali sekalipun menggunakan bahan najis dalam proses penghasilannya. Justeru, Majelis Ulama Indonesia menetapkan hanya vaksin halal sahaja (yang diperakukan halal oleh Majelis Ulama Indonesia) yang boleh digunakan kepada jemaah haji dan umrah di Indonesia. Keharusan menggunakan vaksin yang mengandungi sumber babi disebabkan darurat (keperluan terdesak) tidak relevan lagi digunakan. ${ }^{19}$

Fatwa yang dikeluarkan oleh Majelis Ulama Indonesia jelas mengharamkan masyarakat Indonesia menggunakan vaksin jenama Mencevax keluaran GlaxoSmithKline yang dihasilkan di Belgium. Majelis Ulama Indonesia secara ketat menolak sepenuhnya penggunaan vaksin yang menggunakan unsur daripada babi dalam proses penghasilannya apatah lagi apabila terdapat alternatif lain semasa fatwa ini dikeluarkan. Hendra Utama menjelaskan dua vaksin halal yang mendapat perakuan halal oleh MUI tidak mengandungi unsur daripada babi. Walau bagaimanapun, vaksin jenama 'Menveo Meningococcal Group A, C, W135 and Y Conyugate Vaccine' keluaran Novartis Vaccine and Diognostics S.r.i. dan vaksin jenama 'Menveo Meningococcal Vaccine' keluaran Zheijiang Tianyuan Bio Pharmaceutical Co. Ltd. telah menggunakan bahan najis semasa proses penghasilannya namun ia dapat disucikan setelah melalui proses penyucian yang sejajar dengan hukum syarak. Ini selaras dengan kaedah fiqh yang menyatakan bahawa bahan najis apabila berubah keadaannya (menjadi suatu bahan lain) maka hukumnya menjadi suci (إن ${ }^{20}$ dan perubahan sesuatu hukum adalah bergantung kepada perubahan nama (sesuatu bahan) dan perubahan (bahan tersebut pula) bergantung kepada (yang berlaku) pada sifat (ciri-ciri tersebut) (استحالة الأحكام باستحالة) (الأحفالة)

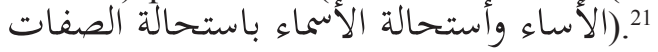

19 Fatwa Majelis Ulama Indonesia, Penggunaan Vaksin Meningitis bagi Jemaah Haji dan Umrah.

20 Maḥmūd Ismā'̄il Muḥammad Misy‘al, Athar al-Khilāf al-Fiqh fì al-Qawā'id al-Mukhtalaf fìhi wa Mad̄̄ Taṭbīquhā fì al-Furū'alMu'āṣarah (Mișr: Dār al-Salām, t.t.), 424.

21 Maḥmūd Ismā‘̄ìl, Athar al-Khilāf al-Fiqh, 424. 
Isu pengharaman vaksin jenama Mencevax oleh Majelis Ulama Indonesia sekali lagi mengejutkan bakal haji dan umrah di Malaysia kerana vaksin ini merupakan satu-satunya vaksin haji yang digunakan sebelum ini. Walau bagaimanapun, fatwa yang dikeluarkan oleh Majelis Ulama Indonesia disangkal oleh Pengarah Urusan Regulatori GlaxoSmithKline, Ellen Wijaya. Beliau menegaskan bahawa vaksin jenama Mencevax keluaran GlaxoSmithKline yang terbaru tidak bersentuhan dengan unsur babi dan menggunakan medium penghasilan yang bebas kandungan haiwan kecuali bahan L-Cystein yang diambil daripada bulu itik. Bahkan, proses penghasilan vaksin jenama Mencevax yang baru telah melalui proses pencucian berulang kali. Oleh sebab itu, Muzakarah Jawatankuasa Fatwa Kebangsaan Malaysia mengharuskan penggunaan vaksin jenama Mencevax di Malaysia. ${ }^{22}$

Pada tahun 2013, Muzakarah Jawatankuasa Fatwa Kebangsaan Malaysia memutuskan bahawa hukum penggunaan vaksin jenama Menveo diharuskan oleh $\operatorname{syarak}^{23}$ kerana terdapat beberapa sumber bahan yang meragukan dalam proses penghasilannya. Ia dijelaskan seperti berikut:

- $\quad$ Transisolate Medium (TIM)

Media ini digunakan dalam proses pemindahan master seed dan terdapat maklumat daripada Pubmed cebtral ia mengandungi sumber gelatin.

\section{- $\quad$ CLAT Selective Agar}

Media ini digunakan dalam proses pemindahan master seed dan bahan yang terkandung di media ini tidak diketahui dengan jelas.

$\overline{22}$ Abd. Rahman, B. Pharm, Vaksin Haji Haram, 43.

23 Kertas untuk Pertimbangan Muzakarah Jawatankuasa Fatwa Majlis Kebangsaan Hal Ehwal Ugama Islam Malaysia, Kedudukan Terkini Proses Penghasilan Vaksin Meningococcal HavaxTM Men ACYW135 dari Perspektif Syarak, Kertas JKF Khas Bil. 3/2013. Lihat juga, Portal Rasmi Fatwa Malaysia, "Hukum Penggunaan Vaksin Meningitis Menveo," laman sesawang Portal Rasmi Fatwa Malaysia, dicapai pada 25 Jun 2015, http://www.e-fatwa.gov. my/fatwa-kebangsaan/hukum-penggunaan-vaksin-meningitismenveo-0. 
- Blood Agar

Media ini digunakan dalam proses pemindahan master seed dan mengandungi darah di mana darah ini berfungsi sebagai makanan kepada pertumbuhan master seed tersebut.

\section{- $\quad$ Meuller Hinton Agar}

Media ini digunakan dalam proses percambahan master seed di Institute Finlay, Cuba. Media ini juga ada digunakan bagi syarikat GSK Pharmaceutical Sdn Bhd dan Novartis Corporation (M) Sdn Bhd dalam pemprosesan awal master seed dan ia mengandungi sumber daripada lembu iaitu casein peptone dan meat extract. Ia juga diragui kehalalan sumbernya sama ada disembelih ataupun tidak.

\section{- $\quad$ L-Cytein}

Bahan ini terdapat dalam liquid media semasa pemprosesan working seed di Institute Finlay, Cuba. Bahan ini boleh didapati daripada bulu itik dan cara mendapat bulu itik dalam keadaan hidup atau setelah disembelih mengikut hukum syarak atau setelah mati tanpa disembelih menurut hukum syarak. MJFK memutuskan penggunaan vitamin D3 yang terhasil daripada bulu binatang yang halal dimakan adalah harus sama ada ia diambil semasa hidup atau selepas disembelih menurut hukum syarak.

- $\quad$ Microfiltration dan ultrafiltration membrane ${ }^{24}$

Penggunaan alat/bahan bantuan pemprosesan iaitu microfiltration dan ultrafiltration membrane di mana kedua-dua filter yang bersumberkan haiwan ini digunakan semasa proses purifikasi bagi mendapatkan hasil yang lebih baik. Akan tetapi microfiltration dan ultrafiltration membrane masih lagi belum mendapatkan pengesahan halal daripada mana-mana badan pensijilan halal.

Pada tahun yang berikutnya, 2014, setelah mendengar penjelasan dan meneliti keterangan daripada pihak Sanofi Pasteur, Muzakarah Jawatankuasa Fatwa Kebangsaan Malaysia turut

24 Kertas untuk Pertimbangan Muzakarah, Kedudukan Terkini Proses Penghasilan Vaksin Meningococcal HavaxTM Men ACYW135, 1116. 
memutuskan bahawa penggunaan vaksin jenama Menomune yang dikeluarkan oleh Sanofi Pasteur adalah diharuskan oleh syarak. ${ }^{25}$

Daripada perbincangan di atas, menunjukkan bahawa keputusan fatwa yang dikeluarkan oleh Muzakarah Jawatankuasa Fatwa Kebangsaan Malaysia terhadap penggunaan vaksin Meningitis adalah diharuskan syarak kerana darurat. Muzakarah Jawatankuasa Fatwa Kebangsaan Malaysia telah mengambil kira pendekatan mașlaḥah darüriyyah bagi tujuan menyelamat nyawa kepada bakal jemaah haji dan umrah di Malaysia. Tambahan pula, sehingga kini masih belum ada vaksin Meningitis yang dihasilkan seratus peratus halal dan suci daripada peringkat awal hingga peringkat akhir penghasilannya. ${ }^{26}$ Ini kerana vaksin meningitis dihasilkan daripada bakteria Neisseria Meningitis yang diperoleh daripada cecair tulang belakang pesakit (najis lighayrih) dan kemudiannya, ia dibiakkan menggunakan media darah yang diambil daripada kuda dan bebiri untuk dijadikan sumber makanan (najis mutawassițah). ${ }^{27}$ Oleh sebab itu, Malaysia tidak memberikan pengesahan halal kepada mana-mana vaksin Meningitis kerana ia tidak memenuhi dengan standard farmaseutikal halal Malaysia. ${ }^{28}$

\section{PERBINCANGAN DAN RUMUSAN}

Berdasarkan kajian yang dijalankan, vaksin Meningitis pada asalnya dihasilkan daripada bakteria Neisseria Meningitis yang diperoleh daripada cecair tulang belakang pesakit (manusia). Bakteria ini kemudian dibiakkan dengan menggunakan media

25 Kertas untuk Pertimbangan Muzakarah Jawatankuasa Fatwa Majlis Kebangsaan Hal Ehwal Ugama Islam Malaysia, Kajian Semula Hukum Penggunaan Vaksin Meningococcal Menomune daripada Status Haram kepada Harus, Kertas JKF Khas Bil. 8/105/2014. Lihat juga, Portal Rasmi Fatwa Malaysia, "Kajian Semula Hukum Penggunaan Vaksin Meninggitis Monumen," laman sesawang Portal Rasmi Fatwa Malaysia, dicapai pada 25 Jun 2015, http:// www.e-fatwa.gov.my/fatwa-kebangsaan/kajian-semula-hukumpenggunaan-vaksin-meninggitis-monumen.

26 Abd. Rahman, B. Pharm, Vaksin Haji Haram, 43.

27 Kertas Untuk Pertimbangan Muzakarah, Kedudukan Terkini Proses Penghasilan Vaksin Meningococcal HavaxTM Men ACYW135, 14.

Abd. Rahman, B. Pharm, Vaksin Haji Haram, 9-10. 
darah yang lazimnya diambil daripada kuda dan bebiri untuk dijadikan sumber makanan. ${ }^{29} \mathrm{Hal}$ ini menunjukkan vaksin Meningitis dihasilkan daripada bahan yang tidak halal daripada awal peringkat proses penghasilannya.

Dalam konteks perubatan Islam, masyarakat Muslim diwajibkan mengambil ubat-ubatan yang halal dan suci. Seperti mana firman Allah SWT dalam surah al- A'rāf ayat ke 157:

Terjemahan: Dan dihalalkan bagi mereka yang baik dan diharamkan ke atas mereka yang jijik (kotor).

Sabda Rasulullah SAW: ${ }^{30}$

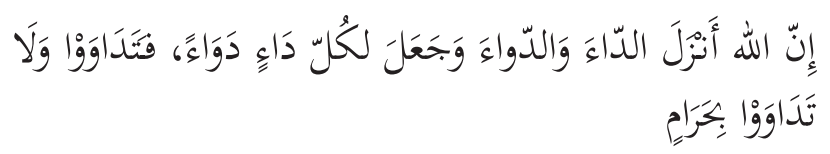

Terjemahan: Sesungguhnya Allah telah menurunkan penyakit dan ubat, dan dijadikan bagi setiap penyakit itu ubatnya, maka berubatlah kamu, dan jangan kamu berubat dengan yang haram.

Berdasarkan kepada nas syarak di atas menjelaskan bahawa bahan haram atau bahan najis tidak boleh digunakan sebagai ubat. Walaupun demikian, dalam keadaan tertentu di mana tidak ada alternatif lain yang boleh dijadikan ubat yang halal maka harus hukumnya mengambil ubat yang bersumberkan haram atau najis. Pengecualian ini adalah berpandukan kepada firman Allah SWT dalam surah al-An'ām ayat ke 119:

Terjemahan: Dan sesungguhnya Allah telah menerangkan kepada kamu satu persatu apa yang diharamkanNya atas kamu, kecuali yang terpaksa kamu memakannya.

29 Kertas Untuk Pertimbangan Muzakarah, Kedudukan Terkini Proses Penghasilan Vaksin Meningococcal HavaxTM Men ACYW135, 14.

30 Abū Dāwūd Sulaymān bin al-Asy'ath al-Sijistānī, Sunan Abū $D \bar{a} w \bar{u} d$, hadith riwayat Abū Dāwūd, Kitāb al-Ṭibb, Bāb fī alAdwiyah al-Makrūhah, no. al-Hadith 2874 (Bayrūt: Dār al-Risālah al-'Ālamiyyah, 2009), 6: 23. 
Nas al-Quran di atas menjelaskan bahawa Islam memberikan keringanan dan kelonggaran kepada penggunaan ubat bersumberkan bahan haram dan najis jika sekiranya keadaan benarbenar darurat. Pengecualian dalam penggunaan bahan haram dan najis sebagai ubat hendaklah menepati beberapa syarat iaitu tidak terdapat atau kesukaran mendapatkan bahan bersumberkan halal untuk mengubati penyakit yang berkaitan, penggunaan bahan berkenaan hendaklah di bawah arahan dan nasihat doktor dan pengambilan ubat daripada bahan haram hendaklah sekadar yang diperlukan sahaja. ${ }^{31}$

Kajian juga mendapati hukum pemberian vaksin adalah bersandarkan kepada sumber bahan yang digunakan dalam penghasilan vaksin berkenaan. Terdapat beberapa bahagian yang telah disebutkan oleh para ulama. Pertama, vaksin yang mengandungi sumber bahan yang harus untuk digunakan serta mempunyai kesan yang bermanfaat. Vaksin ini harus untuk digunakan dan memberi sumbangan yang besar dalam mengurangkan pelbagai wabak yang tersebar. Kedua, vaksin yang mengandungi sumber bahan yang harus untuk digunakan. Akan tetapi ia boleh menyebabkan mudarat yang lebih banyak kepada tubuh badan berbanding manfaatnya. Vaksin ini tidak boleh digunakan kerana boleh memudaratkan kesihatan tubuh badan manusia. Ketiga, vaksin yang mengandungi sumber bahan yang haram atau najis akan tetapi ia telah dirawat dengan bahan kimia ataupun dicampurkan dengan bahan lain lalu berubah kepada bahan baru yang harus untuk digunakan. Ia dikenali sebagai proses istihālah dan mempunyai kesan yang bermanfaat. Vaksin ini harus untuk digunakan kerana proses transformasi yang berlaku telah menukarkan kepada nama dan sifat yang baru dan tidak lagi menyamai dengan nama dan sifatnya yang asal seterusnya mengubah hukum haram kepada harus untuk digunakan. ${ }^{32}$

31 Jabatan Kemajuan Islam Malaysia, Garis Panduan Bersama Kawalan Ubat-ubatan dalam Islam.

32 Muhammad Fahmi Rusli, "Bayan Linnas Siri 59: Vaksin: Sudut Pandang dari Neraca Fiqh \& Maqasid Syariah," laman sesawang Pejabat Mufti Wilayah Persekutuan, dicapai 22 Disember 2016, http://muftiwp.gov.my/index.php/ms-my/perkhidmatan/bayanlinnas/1217-bayan-linnas-siri-59-vaksin-sudut pandang-dari-neracafiqh-maqasid-syariah. 
Merujuk kepada fatwa Muzakarah Jawatankuasa Fatwa Kebangsaan Malaysia pada tahun 2002, 2013 dan 2014, Jawatankuasa Fatwa menetapkan hukum pengambilan vaksin Meningitis ke atas jemaah haji dan umrah adalah harus kerana darurat. Konsep darurat ini masih terpakai selagi mana tidak terdapat alternatif kepada penggunaan vaksin Meningitis yang halal. Agama Islam sangat menitik beratkan kepentingan asasi manusia terutamanya kepada pemeliharaan nyawa dan mengharamkan setiap perbuatan yang boleh menyebabkan pengabaian dan kemudaratan terhadapnya.

Menurut Mufti Wilayah Persekutuan, Sahibus Samahah Datuk Dr Zulkifli Mohamad al-Bakri, hukum pengambilan suntikan vaksin adalah diharuskan syarak jika menepati beberapa kriteria berikut iaitu berlakunya keperluan yang mendesak, ianya telah pun dibuktikan dapat memberikan kesan yang baik, elakkan bahan yang bersifat najis kecuali jika dalam keadaan terpaksa, sifatnya (vaksin) sebagai pengawalan daripada penyakit telah terbukti dan tiada kesan sampingan dan mudarat yang lebih besar berlaku kepada pesakit yang disuntik dengan vaksin. Jika semua kriteria ini dapat dipenuhi maka pengambilan vaksin akan menjadi satu keperluan kepada manusia selaras dengan realiti kehidupan di zaman mutakhir ini. ${ }^{33}$

Malaysia juga dengan tegas tidak akan memberikan sijil halal kepada vaksin Meningitis kerana tidak memenuhi kriteria halal seperti mana yang ditetapkan dalam standard farmaseutikal halal Malaysia, MS 2424:2012: Farmaseutikal Halal: Garis Panduan Umum. Vaksin yang dikategorikan sebagai halal adalah vaksin yang mengandungi ciri-ciri berikut, iaitu (a) tidak mengandungi mana-mana bahagian atau produk haiwan yang tidak halal dari segi syarak atau mana-mana bahagian atau produk haiwan yang tidak disembelih mengikut hukum syarak; (b) tidak mengandungi najis menurut hukum syarak; (c) selamat dimakan, tidak beracun, tidak memabukkan atau tidak merbahaya kepada kesihatan mengikut dos yang di preskripsi; (d) tidak disediakan, diproses atau di kilang menggunakan peralatan yang tercemar dengan najis menurut hukum syarak; (e) tidak mengandungi mana-mana bahagian manusia atau hasilan daripadanya yang tidak dibenarkan

33 Muhammad Fahmi Rusli, "Bayan Linnas Siri 59". 
oleh hukum syarak; dan (f) semasa penyediaan, pemprosesan, pengendalian, pembungkusan, penyimpanan dan pengedarannya, produk farmaseutikal halal dipisahkan secara fizikal daripada mana-mana produk farmaseutikal lain yang tidak memenuhi keperluan yang dinyatakan dalam butiran a), b), c), d), atau e) atau mana-mana butiran yang telah di hukumkan sebagai tidak halal dan najis menurut hukum syarak. ${ }^{34}$ Justeru, vaksin yang tidak memenuhi kriteria (a) hingga (f) maka vaksin tersebut adalah vaksin haram namun begitu harus digunakan kerana darurat.

Indonesia pula mengambil langkah yang berbeza dengan Malaysia. Indonesia dengan tegas mengharamkan penggunaan vaksin Meningitis jenama Mencevax keluaran GlaxoSmithKline kerana mengandungi bahan haram (babi) dalam pemprosesannya. Ini adalah kerana terdapat alternatif lain yang boleh digunakan dalam kalangan jemaah haji dan umrah iaitu vaksin halal. Oleh itu, keharusan menggunakan vaksin yang mengandungi bahan haram tidak lagi dibenarkan kerana tiada keperluan yang mendesak. ${ }^{35}$

Meskipun terdapat perbezaan pandangan antara Malaysia dan Indonesia terhadap isu ini, namun kedua-dua buah negara sangat mementingkan pemeliharaan nyawa terhadap jemaah haji dan umrah. Ini kerana maṣlahah darūriyyah adalah peringkat pertama dalam kedudukan mașlaḥah yang mesti diutamakan berbanding dengan maṣlaḥah hājiyyah dan maṣlaḥah taḥsiniyyah. Tambahan pula, tanpa suntikan vaksin Meningitis akan mendedahkan jemaah haji dan umrah kepada mudarat yang besar dari segi kesihatan seperti kerosakan otak, hilang pendengaran, kurang upaya pembelajaran dan kematian. ${ }^{36}$ Kaedah fiqh menyatakan bahawa mencegah kemudaratan lebih diutamakan daripada mencari

\footnotetext{
34 Jabatan Standard Malaysia, MS 2424:2012: Farmaseutikal Halal: Garis Panduan Umum (Putrajaya: Jabatan Standard Malaysia, 2012), 1-2.

35 Hendra Utama (Kepala Bidang Standar, Lembaga Pengkajian Pangan, Obat-obatan dan Kosmetika Majelis Ulama Indonesia (LPPOM MUI), Kota Bogor, Indonesia), dalam temu bual dengan penulis, 11 Mei 2015. Lihat juga, Fatwa Majelis Ulama Indonesia, Penggunaan Vaksin Meningitis Bagi Jemaah Haji dan Umrah, Nomor: 06 Tahun 2010, Majelis Ulama Indonesia.

36 Abd. Rahman, B. Pharm, Vaksin Haji Haram, 43.
} 
maṣlahah (دري المفاسد مقدم على جلب المصالح) dan keperluan

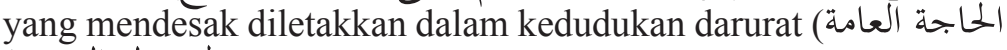
(تنزل منزلة الضرورة paling ringan di antara dua mafsadah dilakukan dengan tujuan untuk mengelakkan mafsadah yang lebih besar apabila tidak boleh untuk disepakati antara salah satunya. Dalam erti kata yang lain, apabila bertembung dua mafsadah atau keburukan maka hendaklah mengambil atau menggunakan mafsadah yang lebih ringan kesannya.

\section{RUMUSAN}

Islam merupakan agama yang syumul dan memberikan garis panduan umum kepada seluruh masyarakat Muslim dalam semua aspek kehidupan termasuk yang berkaitan dengan kesihatan. Dalam keadaan yang biasa, Islam mewajibkan Muslim mengambil sumber vaksin yang halal dan suci. Walau bagaimanapun, jika tidak dapat dielakkan vaksin yang bersumberkan haram dan najis diharuskan kerana darurat namun penggunaannya sekadar yang perlu sahaja.

Berdasarkan kajian, hukum pengambilan suntikan vaksin Meningitis jenama Mencevax diharuskan di Malaysia. Hal ini berbeza dengan Indonesia yang mengharamkan suntikan vaksin Meningitis jenama Mencevax kerana audit yang dijalankan mendapati vaksin ini pernah bersentuhan dengan unsur babi dalam penghasilannya. Justeru, masyarakat awam Indonesia disarankan supaya mengambilkan suntikan vaksin halal seperti mana yang disyorkan oleh Majelis Ulama Indonesia. Vaksin halal berkenaan tidak pernah bersentuhan dengan unsur babi meskipun bersumberkan bahan yang najis. Akan tetapi, ia dapat disucikan melalui proses penyucian berulang yang selaras dengan hukum syarak lalu menghasilkan vaksin baru yang halal.

Kajian mendapati bahawa terdapat perbezaan yang ketara dari sudut metode pengeluaran fatwa yang dikeluarkan di

37 Ibrāhīm Muhammad Maḥmūd al-Ḥarīrī, al-Madkhal ilā al-Qawā id al-Fiqhiyyah al-Kulliyyah ('Ammān: Dār 'Ammār li al-Nasyr, 1998), 97.

38 Al-Ḥarīrī, al-Madkhal, 89. 
antara Malaysia dan Indonesia. Muzakarah Jawatankuasa Fatwa Kebangsaan Malaysia mengharuskan pengambilan suntikan vaksin jenama Mencevax berasaskan pendekatan akhaf aldarārayn dan mașlahah darūriyyah untuk tujuan menyelamatkan nyawa. Malaysia juga tidak memberikan pengesahan halal kepada vaksin Meningitis kerana ia tidak selaras dengan standard farmaseutikal halal Malaysia, MS2424:2012. Manakala, Majelis Ulama Indonesia mengharamkan pengambilan suntikan vaksin jenama Mencevax dan mewajibkan jemaah haji dan umrah di Indonesia mengambil suntikan vaksin halal kerana prinsip darurat tidak relevan lagi digunakan.

Dapat disimpulkan bahawa Islam mementingkan penjagaan kesihatan serta menyarankan supaya mengambil langkah pencegahan yang lebih awal sebelum berlakunya sesuatu yang boleh mendatangkan kemudaratan tubuh badan. Tindakan mengambil suntikan vaksin merupakan satu kewajipan supaya dapat membendung gejala penyakit berjangkit dari peringkat awal di samping mengelakkan mafsadah yang lebih besar kepada masyarakat awam. Meskipun terdapat sesetengah dakwaan daripada golongan anti vaksin yang mengatakan suntikan vaksin yang diberikan mengandungi bahan haram dan najis namun begitu sekiranya tiada alternatif yang lain maka penggunaan vaksin tersebut diharuskan kerana darurat. Diharapkan kajian ini dapat menyelesaikan salah faham berkaitan isu vaksin yang berlaku dalam segelintir kalangan masyarakat awam di Malaysia dan Indonesia. 


\section{RUJUKAN}

Abd. Rahman, B. Pharm. Vaksin Haji Haram. H. Science Solution: RBC Publishing \& Marketing, 2013.

Abū Isḥāq al-Syāṭibī Ibrāhīm bin Mūsā. Al-Muwāfaqāt fì 'Ilm Ușūl al-Syarī'ah. Bayrūt: Dār al-Kutub al-'Ilmiyyah, 1991.

Adnān Muhammad Jum'at, Raf' al-Haraj fì Syarī'ah alIslāmiyyah. Ed. ke-3. Dimasyq: Dār al-'Ulūm Insāniyyah, 1993.

Al-Asyqār, 'Umar Sulaymān 'Abd Allāh. Nazariyyat fì Ușūl alFiqh. Jordān: Dār al-Nafā' is, 1999.

Al-Ghazālī, Abū Ḥāmid Muḥammad bin Muḥammad. Al-Mustașāà min 'Ilm al-Ușūl. Al-Madīnah: Syirkah al-Madīnah alMunawwarah li al-Tibā'ah wa al-Nasyr, 1992.

Al-Ḥarīrī, Ibrāhīm Muhammad Maḥmūd. Al-Madkhal ilā alQawā 'id al-Fiqhiyyah al-Kulliyyah. 'Ammān: Dār 'Ammār li al-Nasyr, 1998.

Al-Rāzī, Fakhr al-Dīn Muhammad bin 'Umar bin Husayn. AlMahșūl fì 'Ilm Ușūl al-Fiqh. Bayrūt: Mu'assasah al-Risālah, 1992.

Al-Sijistān̄i, Abū Dāwūd Sulaymān bin al-Asy'ath. Sunan Abū Dāwūd. Bayrūt: Dār al-Risālah al-'Ālamiyyah, 2009.

Fatwa Majelis Ulama Indonesia, Penggunaan Vaksin Meningitis Bagi Jemaah Haji dan Umrah, Nomor: 06 Tahun 2010, Majelis Ulama Indonesia.

Fatwa Majelis Ulama Indonesia. "Vaksin Meningitis Italia \& China Halal (Untuk Calon Jemaah Haji dan Umrah)". Laman sesawang Majelis Ulama Indonesia. Dicapai pada 15 November 2013, https://www.facebook.com/notes/majelisulama-indonesia-mui/vaksin-meningitis-italia-china-halaluntuk-calon-jemaah-haji-dan-umrah/225948397468893.

Ḥusayn Ḥāmid Hasān. Naẓariyyah al-Mașlahah fì al-Fiqh alIslāmī. Al-Qāhirah: Maktabah al-Mutanabbi, 1981. 
Ibn Manẓūr al-Afrīqī al-Miṣrī. Lisān al- 'Arab. Bayrūt: Dār Șādir, 1990.

Jabatan Standard Malaysia. MS 2424:2012: Farmaseutikal Halal: Garis Panduan Umum. Putrajaya: Jabatan Standard Malaysia, 2012.

Kertas untuk Pertimbangan Muzakarah Jawatankuasa Fatwa Majlis Kebangsaan Hal Ehwal Ugama Islam Malaysia. Kajian Semula Hukum Penggunaan Vaksin Meningococcal Menomune daripada Status Haram kepada Harus, Kertas JKF Khas Bil. 8/105/2014.

Kertas untuk Pertimbangan Muzakarah Jawatankuasa Fatwa Majlis Kebangsaan Hal Ehwal Ugama Islam Malaysia, Kedudukan Terkini Proses Penghasilan Vaksin Meningococcal HavaxTM Men ACYW135 Dari Perspektif Syarak, Kertas JKF Khas Bil. 3/2013.

Kotb Rissouni dan Najmaldeen K. Kareem al-Zanki. “Application of Maqasid in the Jurisprudence of Minorities: The Case of "Zawaj al-Maslahah" in the West". Jurnal Fiqh 12 (2015), 141.

Portal Rasmi Fatwa Malaysia. "Kajian Semula Hukum Penggunaan Vaksin Meninggitis Monumen." Laman sesawang Portal Rasmi Fatwa Malaysia. Dicapai pada 25 Jun 2015, http:// www.e-fatwa.gov.my/fatwa-kebangsaan/kajian-semulahukum-penggunaan-vaksin-meninggitis-monumen.

Maḥmūd Ismā‘īl Muḥammad Misy'al. Athar al-Khilāf al-Fiqh fì al-Qawā id al-Mukhtalaf fìhi wa Madā Taṭbìquhà fì alFurū' al-Mu 'ạṣarah. Mișr: Dār al-Salām, t.t.

Malina Osman. "Vaksin: Menerima Pendapat Pakar." Laman sesawang Utusan Online. Dicapai 22 Disember 2016, http:// www.utusan.com.my/rencana/vaksin-menerima-pendapatpakar-1.364684.

Mohamad Zaidi Abdul Rahman. "Aplikasi Maqasid al-Shari'ah dalam Pentadbiran Negara: Satu Tinjauan Sejarah Islam.” Jurnal Fiqh 12 (2015).

Mohd. Nor Deris. "Keterikatan Mașlaḥah Sebagai Sumber 
Hukum dengan Kepentingan Semasa dan Setempat di Malaysia." Dalam Fiqh Malaysia. Ed. Paizah Ismail dan Ridzwan Ahmad. Universiti Malaya: Akademi Pengajian Islam, 2000.

Muhammad Fahmi Rusli. "Bayan Linnas Siri 59: Vaksin: Sudut Pandang dari Neraca Fiqh \& Maqasid Syariah." Laman sesawang Pejabat Mufti Wilayah Persekutuan. Dicapai 22 Disember 2016, http://muftiwp.gov.my/index.php/ms-my/ perkhidmatan/bayan-linnas/1217-bayan-linnas-siri-59vaksin-sudut pandang-dari-neraca-fiqh-maqasid-syariah.

Mustafa Abdul Rahman. Kertas Kerja Muzakarah Jawatankuasa Fatwa Majlis Kebangsaan Hal Ehwal Ugama Islam Malaysia. Hukum Suntikan Pelalian Vaksin 'Meningococcal Quadrivalent' oleh Orang Islam, Kertas JKF Bil. 1/53/2002, 2.

Portal Rasmi Fatwa Malaysia. "Suntikan Pelalian Vaksin Meningococcal Meningitis oleh Orang Islam." Laman sesawang Portal Rasmi Fatwa Malaysia. Dicapai pada 24 Jun 2015, http://www.e-fatwa.gov.my/fatwa-kebangsaan/ suntikan-pelalian-vaksin-meningococcal-meningitis-olehorang-islam.

Quṭb Mușțaā Sānū. Mu jam Mușțalahāt Ușūl al-Fiqh. Bayrūt: Dār al-Fikr, 2000.

Tabung Haji. "Maklumat Imunisasi." Laman sesawang Tabung Haji. Dicapai pada 24 Jun 2015, http://www.tabunghaji. gov.my/maklumat-imunisasi. 
Jurnal Fiqh, No. 14 (2017) 27-50 